\title{
Research on the Teaching Mode of the Ideological and Political Theory Course in the New Media Era
}

\author{
Zhang Hongjie \\ Feixian Branch School, Linyi University
}

\begin{abstract}
With the advent of the new media era, which is characterized by information, digitalization and networking, it is the opportunity for the ideological and political theory course in Colleges and universities, and it also challenges the traditional teaching mode of Ideological and political education.To meet the new requirements of the new media era, we must innovate the educational ideas and reform the teaching mode. In the context of the new media, we should adopt a variety of teaching modes, combining classroom teaching and network teaching in order to build a new model of Ideological and political theory teaching which is comprehensive and open.
\end{abstract}

Keywords- new media;ideological and political theory course in Colleges and universities;teaching mode;network teaching

In the era of new media technology, computer, mobile phone and many other electronic products with powerful information search and storage function are increasingly becoming an integral part of the study of college students. New media platform has become an important platform for college students to acquire knowledge, to understand the information, to observe the society and to shape the self. The StatisticsReport of the Twenty-fourth China Internet Development shows that $95 \%$ of college students will take the internet as an important channel ofinformation. Facing the opportunities and challenges brought by the new media, how to play the role of the main channel of the ideological and political education to the students in Colleges and universities, and to guide the diversified social thoughts in the socialist core value system has become a major issue to be faced by the teachers of the ideological and political theory course.

\section{A NEW SITUATION OF THE IDEOLOGICAL AND POLITICAL THEORY COURSE IN COLLEGES AND UNIVERSITIES IN THE NEW MEDIA ERA}

\section{A. The opportunity the College Ideological and political} theory course teaching faces in the new media era

The new media network has a high degree of openness and interactivity, and it expands vast space to Ideological and political theory course teaching.It also broadens the horizon of the college students ,expand the coverage of education and strengthen the actual effects of teaching. People can use the new media platform to experience the existence of others.At the same time,he can present the existence of himself to others. Teachers can use this feature to find out the characteristics of College Students' psychological confusion, ideological status and their most concern. In this way ,they can get the entry point to the Ideological and political education and proceed the teaching activities with specific target so as to improve the effectiveness of Ideological and political theory course teaching.

The quickness of the new media network information and the phenomenon of "cultural feedback" based on network, promote the ideological and political theory teaching to keep pace with the times. In the present time, the teacher has lost the advantage of information resources in the past, because the students can obtain the required knowledge at any time in any place. More than that, good English foundation, skilled computer operation skills and active thinking almost make the young monopolize the network and its information.With their new knowledge, new ideas and new norms of behaviour,they nurture teachers' knowledge structure, value idea and behavior way, forcing the ideological and political theory teachers to go beyond the tedious theory of Xuan grant and adhere to the theoretical quality of keeping pace with the times. Acting in accordance with the Marxist stand, viewpoint and method,the teachers made timely response and rational analysis to social hot issues which is prevalent in the network and attracts the students' concern. At the same time, adhere to the correct guidance of public opinion, to eliminate the students' confusion in the ideology, to help them improve the ability to analyze and solve practical problems, so that the ideological and political theory courses come more close to the students, to the reality, and to life.And to make what they learn useful.

The new media network has huge reserves of information .It can provide a variety of ideas andmaterials for political theory course teaching . Thus it greatly enrich the teaching activity. The network has strong communication advantages, which provides an open interactive communication mode for the ideological and political theory course teaching activity.So it becomes the important platform for the students to obtain knowledge and exchange ideas.

\section{B. The challenges College Ideological and political theory course teaching face in the new media era}

The opening of the new media can easily lead to the diversification of College Students' values. The multitude of network information provides abundant information for students' learning and research, broaden students' horizons.However, it's difficult to tell good from bad network information.some unhealthy, false, wrong and even reactionary content may cause serious information 
pollution.Thus it reduces the degree of clarity and utilityof the information. College students are active in their thinking. They are less constrained and more inclusive of different cultures and values. They are weak in the choice of information and the ability to filter information.They can't identify the information properly. So they are very vulnerable to the impact of bad information, leading to the fragmentation of their mainstream ideology. In particular, cultural and political ideas of western hegemony after careful packaging blur their sight.The erosion on their world outlook of life and value and the world,on the traditional moral, ethical, national spirit leads to the loss of College Students' culture and the fracture of the cultural foundation, causing serious faith crisis. To the college students in the social transformation period, it is necessary to bring the diversification of the value, and concept.And it also increase the difficulty to maintain the national identity and the common values.

The virtual nature of the new media network can easily lead to the non - human tendency of college students. Social interaction is the basic needs of people, and the new virtual survival mode of the new media network turns the communication between people into communication between people and machines.And the traditional social intercourse between people will be replaced by the dependency between people and the network. The ties of social links become increasingly lax, eventually leading to a weak sense of community and loose structureof a variety of communities. Some students indulge in the network virtual world to escape the reality, prone to non - human tendency.

The disorder of the new media network can easily lead to the behavior anomie of some college students. The disorder and anonymity of the new media network make all kinds of "ideological barriers" online useless. Online behavior can not restricted by the public opinion and traditional moral concept. Thus, a dual personality comes into being. It easily leads to the behavior anomie of some college students. Among the network crime crowds, college students is one of the high-risk group. It is in contrast The students in of, worthy of attention.to the low crime rate in general incidence, which should bevalued.

In short, the single teaching model in the past can not be able to meet the needs of Ideological and political theory course teaching in the new media era. We need to explore a teaching mode adapt to the new media era.

\section{THE INNOVATION OF IDEOLOGICAL AND POLITICAL} THEORY COURSE TEACHING MODE IN COLLEGES AND UNIVERSITIES UNDER THE BACKGROUND OF THE NEW MEDIA .

Adapting to the new situation, aiming at the characteristics of College Students' physical and mental development, following the requirements of the law of education and teaching, exploring new teaching mode is the key to the reform of Ideological and political theory in Colleges and universities. Twenty-first Century is the information society. The rapid development of information technology will bring revolutionary change to the teaching. Under the background of new media, adopting a variety of teaching modes of classroom teaching and combining classroom teaching and network teaching to build a comprehensive, open new mode of ideological and political theory course teaching will become the development trend of deepening the reform of ideological and political theory course teaching. The new mode of ideological and political theory course teaching gives priority to classroom teaching, with network teaching as a necessary supplement It also realizes the complementary advantages, optimizes the teaching process and strengthens the teaching effect.

A. New media era should give full play to the main position and main channel of ideological and political theory teaching in the classroom.

Under the new media era, the ideological and political theory course teachers have been unable to leave the new media technology and new media tools. Ideological and political theory teachers can use new media network resources and new media platforms to make PPT courseware or CAI courseware so as to enrich teaching content, activate students' thinking and open the spiritual intelligence of students.

In the new media era, ideological and political theory course teachers should strengthen ideological and political theory course for the integration function of social ideology, adhere to the unified leading the diversified.The famous American futurist $\mathrm{Mr}$ Alwan, toffler said: " whoever has mastered the information and controlled the network will have the whole world." The network environment has broken through the time and space obstacles of different cultural exchange and fusion. The coexistence of diverse cultural ideas and value ideas is inevitable.This requires teachers of Ideological and political theory course to master the network technology. They must actively spread marxism-leninism and MAO zedong thought and theoretical system of socialism with Chinese characteristics at the same time. In the dialogue and coexistence with all kinds of cultures,to adhere to use the socialist core value system to shape people's ideal, conviction, morality, and lead the basic direction of the culture to the level of "being harmony but not the Same", so as to effectively play the role of social ideology orientation and integrationof ideological and political education.The Party's EighteenthCongress clearly put forward: "to advocate prosperous, democratic, civilized and harmonious, advocating freedom, equality, justice, rule of law, advocates patriotic, dedicated, honest, friendly, and actively cultivate and practice the socialist core values".Socialist core values is the kernel of the system of socialist core values. The socialist core value system is the essence of socialist ideology. It has a wide range of appeal, charisma and the theory dominated the basic direction of the entire value system.Therefore, the ideological and political theory course teachers must make full use of various network resources to guide students to agree and accept the system of socialist core values, and make it the value measure to identify, to resist and overcome the negative influence of various error values.On the basis of respect for differences, we should allow diversity and always maintain the whole society's common ideal faith, forming the whole nation's spirit of striving to make progress.

In the era of new media, political theory course teachers should strive to improve their own quality, closely tracking the new situation and new characteristics of social development, scientifically design the teaching 
content, highlight the "three represents" important thoughts and the scientific outlook on development and the spirit of a series of Xi Jinping's speech; They should be close to the characteristics of the era, close to the college students' thoughts, close to the social life;Constantly improve the ideological and political theory course construction, reform the organization of the teaching methods, teaching means and design, They should change from the teachers'teaching to discussing the questions and students between trachers and students, from the single classroom teaching method to the combination of diversified teaching methods . They should also pay attention to the long-term development of college students and cultivate students' ability of independent thinking.

B. The new media age should give full play to interactive role of the network teaching.

Under the background of the new media network, the ideological and political theory teachers can use online classroom, teacher's blog wth issues, mobile phone text messages, chat rooms and other platform to realize zero distance communication with no gap and less constraints with the students, and also communicate intheir souls. Thus they can exert influence on the students through new media .

1) The operation of the network teaching of ideological and political theory course.

Under the new media background, on the one hand, the new model of Ideological and political theory teaching in Colleges and universities stresses the guidance and the dominance of the ideological and political theory course teachers in the teaching of the course; on the other hand, it also attaches great importance to the students' "center" position and independent learning in the teaching process.Therefore, the ideological and political theory teaching in colleges and universities should follow the following procedures.

First,toregistrate certification onlin,and be prepared before class.Before the organization and implementation of network teaching, first of all, the teachers and students should make online registration certification in order to establish a link between the network support and online communication between teachers and students. This is an essential link in the network teaching of Ideological and political theory course in Colleges and universities. It is related to the smooth implementation of the ideological and political theory course network teaching.

Second, release information, arrange the teaching activities. After the teacher's online registration is successfully entered into the main interface of the network platform, the teaching requirements, teaching content, the selected teaching cases, and the hot issues will be published in the online classroom.students of different classes can download different teaching cases.After the students receive the teaching cases, according to the teaching requirements, they can carry out autonomous learning under the teacher's guidance. through the network to, can make seriously independent thinking on the reference materials in the online reading teaching resources management module. They can also through online communicate with the teachers or to discuss with other students online And they should write teaching case analysis report independently.
Third ,organize online discussion, submit analysis report.In the completion of autonomous learning, teachers can organize students to discuss in groups and form group reports according toquestions of the teaching cases.During the group discussion, the students can compare the teaching case report and the results of the group discussions so as to deepen the understanding of knowledge, to strengthen the ability to analyze and solve problems.. After the discussion, the students will submit the analysis report to the teacher through the network.

The fourth teaching evaluation and information feedback.Is the last link in network teaching, teachers' grading the students online analysis report, after being automatically generated achievement scores, then through the network will review the result feedback to students.Students refer to ratings at the same time can also through the network communication with teachers, in order to improve teaching effectiveness.

Fourth teaching evaluation and information feedback. The last part of the network teaching, teachers comment students' analysis report online.After automatically generated through the system, scores are feeded back to students through the network. Students access to the results of the score, but also they can communicate with teachers through the network to improve the effectiveness of teaching.

2)The characteristics of the ideological and political theory network teaching

As we all know, the network is open and virtual.In the network teaching of the ideological and political theory, communication between teachers and students is no longer limited to the face.It broke the traditional "classroom teaching" in the form of regional teaching organization.Teaching is no longer subject to time and space constraints.No matter at any time, no matter in what place, as long as you have access to the Internet, students can acquire knowledge through new media platform, and teachers can flexibly use collaborative teaching, individual teaching and other forms to enhance the selectivity and autonomy of students' learning and teachers' teaching pertinence, and to make organization forms of teaching more flexible and varied.And new media technologies have vivid, intuitive, image, concrete, and the advantages of large amount of information, in a variety of elements to attract the attention of students, make students sense of hearing, vision and other senses stimulated, reflects the characteristic of the new media era.Moreover, the new media technology has many advantages, such as vivid, intuitive, vivid, concrete, and so on, with many elements to attract the attention of students, so that it will stimulate the students' sense of hearing, vision and other senses. It will also stimulate their enthusiasm of abstract theories.All these reflect the characteristics of the new media era.

The relationship between teaching and learning under the network environment, status has changed, the ideological and political theory course network teaching model.The relationship between teaching and learning under the network environment has changed, the network teaching mode of Ideological and political theory in Colleges and universities has new characteristics. The teachers have changed from the knowledge transmitter and instiller into the students' learning guides and information navigator. They are no longer the dominant role of 
teaching. The role of teachers is mainly the development and construction of learning resources and the organization of classroom learning. students from of knowledge into knowledge, the concept of active construction, as the main body of learning and teaching activities of the main participants, achieve the goal of ideological and political education. The students have changed from the original passive recipients of knowledge to the active constructer of knowledge, concept, and become the main participants in the learning and teaching activities, to achieve the goal of Ideological and political education.

Network teaching is a kind of brand-new teaching mode. Teaching content, teaching methods, the time and place of teaching, including guiding teacher can completely be chosen according to the student individual need to choos. The students become the center of the learning and the main bodyof teaching activities This is in line with the modern college students' psychological needs, thus strengthening the subject status of students in teaching.

The development of the network teaching of ideological and political theory in college and universities, effectively build the interactive dynamic teaching mode, teachers and students to realize the college students from the "recipient" to "participants", , truly reflects the teacher's dominant position in the ideological and political theory course teaching and student's main body status, will be to adapt to, the inevitable choice.

The development of the network teaching of Ideological and political theory in Colleges and universities has effectively built up the dynamic teaching mode of teacher and student interaction.It realizes the change of the students from the "recipients" to "participants", and gives full play to the students' enthusiasm and initiative. It truly reflects the teacher's dominant position and the students'subject status in the ideological and political theory course teaching. It is the inevitable choice of ideological and political theory teaching the develop high-quality talents which adapt to the future information society.

\section{REFERENCES}

[1] Ding Yun ,Lu Wenyi. A Preliminary Study on College Students' Network Illegal Crime Problem [J]. Journal The Illegal Crime Problem of juvenile crime 2005 (5) : 12.
[2] Lliu zhaohua, Zhang Yanjun. Some Thoughts on the Teaching Reform of theIdeological and Political Theory Course in the New Period 2007 (3) : 101I. S. Jacobs and C. P. Bean, "Fine particles, thin films and exchange anisotropy," in Magnetism, vol. III, G. T. Rado and H. Suhl, Eds. New York: Academic, 1963, pp. 271-350.

[3] YanShuang. Thoughts on Some Issues about Education Courses in Colleges and Cniversities [J]. Journal of Exploration and Schools of Tthought Contend, 2010 (8) : 43

[4] Zhong Ying. Network Communication Ethics [M]. Beijing: Tsinghua University Press, 2005:162

[5] Yang Huaizhong, Cheng Hongyan. The Challenge of New Media to Ideological and Political Theory Course Teaching and Innovation of Evaluation Mechanism [J]. Journal of Higher Education Development and Evaluation. 2012 (3) : 117

[6] chun-yan zhou. The Teaching Model Research of Ideological and Political Course under the Background of the Network [J]. Journal of EducationInformationization in China, 2008 (23) : 68

[7] Luo Chengyi. Theory of the Socialist Core Value System into Iideological and Political Education [J]. Journal of Social Science in Hunan, 2007 (4) : 153

[8] Hou Yunxia, Yu Jinxiu. "Network Dialogue" to Improve Actual Effect of Iideological and Political Theory Course [J]. Journal of Audio-visual Education Research. 2007 (12) : 60-62

[9] Kou Hechao, Zhang Xiao. A Preliminary Ananlysis on the Network of Ideological and Political Theory Course in Colleges and Universities [J]. Journal of West China Normal University: Philosophy and Social sciences. 2007 (3): 72-73

[10] Ceng Weilun, Dai Jinping. Research on Network Teaching Mode of Ideological and Political Theory [J]. Journal of Moral Education in China. 2006

[11] Michael Heim. From the Interface to the Network Space: the Metaphysics of Virtual Reality [M]. Shanghai: Shanghai Scientific and Technological Education Publishing House, 2000.

[12] Song Yawei. The Optimization of the Network Environment of Ideological and PoliticalEducation in Colleges and Universities [J]. Henan Social Sciences.2005 (3): 143

[13] Zhao Yafang. Practice and tThinking of Network Teaching in Ideological and Political Theory Course. Journal of Jixi University 2008 (2): 45

[14] Zhang Meihua. The Construction of theInteractive Teaching Mode of Ideological and Political Ttheory Course in Colleges and Universities [J]. Higher Vocational Education: Journal of Tianjin Vocational Institute,.2012,21 (3): 82-84

[15] Wang Xuejian, Li Xinke. Research on the Problems and Countermeasures of Ideological and Political Theory Course in Colleges and Universities:.2006 (2): 78-80

[16] Zhu Lin, Zhang Jianxun, Zheng Chao. Research on the Interactive Teaching Platform of Ideological and Political Theory Course in Colleges and Universities Based on Social Network Service. [J] Journal of Ideological and Political Education Research.2011,27 (4):73-76. 